To appear in JCMS: Journal of Common Market Studies 2017:

Early View URL:

http://onlinelibrary.wiley.com/doi/10.1111/jcms.12579/full

\title{
Benchmarking Brexit: \\ How the British Decision to Leave Shapes EU Public Opinion
}

Catherine E. De Vries

Department of Government

University of Essex

Wivenhoe Park

CO4 3SQ Colchester

United Kingdom

catherine.devries@essex.ac.uk 
The British are of course testing us, we all know that.

They are testing how united Europe actually is.

So what is important is that Europe stays together.

Vice-President of the European People's Party,

David McAllister, 19 November $2016^{1}$

\title{
Benchmarking Brexit: \\ How the British Decision to Leave Shapes EU Public Opinion*
}

\author{
CATHERINE E. DE VRIES \\ University of Essex
}

\section{Introduction}

On 23 June 2016, by a small majority the British population voted to leave the European Union (EU). The British decision to leave shocked the political establishment in London, Brussels and beyond. Immediately after the vote, the pound fell sharply as uncertainty among investors about Britain's economic future started to grow. Politically, the situation was not much different. Not only did Prime Minister David Cameron resign, but the referendum result unmasked deep divisions between different regions and amongst the constituent components of the United Kingdom as well as within the two major political forces in Westminster, the Conservative and Labour parties. New Prime Minister Theresa May was confronted

\footnotetext{
${ }^{1}$ The Guardian, 19 November 2016.

* I would like to thank the editors of the JCMS Annual Review, especially Tim Haughton, for excellent comments on a draft of this paper as well as Sara Hobolt, Hector Solaz, Christina Schneider and Stefanie Walter for discussions about the arguments presented here more generally.
} 
with the daunting task of negotiating British withdrawal from the EU whilst keeping her party and country together at a time when the exact economic costs of Brexit are still highly uncertain. While the British economy weathered the vote and its immediate aftermath better than expected, long-term assessments of a post-Brexit British economy are less rosy. ${ }^{2}$ This might be at least in part the result of the Brittish government's decision to delay the triggering of Article 50. The market response following the invoking of the article seems to suggest as such.

Although the reasons behind Britain's decision to quit the EU have received ample scholarly attention already (Goodwin and Heath, 2016; Hobolt, 2016; Clarke et al., 2017), the consequences of the vote for public support for the EU and the future of the European project have received less attention in the scholarly debate. Speculation among politicians and pundits has moved in two directions. Some suggest that the Brexit vote might turn out to be a unifying moment for Europe. The political paralysis that emerged from the fundamentally different viewpoints in the European bloc about how to tackle the eurozone and refugee crises could give away to a more coordinated and European approach. Comments by Xavier Bettel, the prime minister of Luxembourg, at the intergovernmental conference held in Brussels following the result of the British referendum reflected this view: 'We have more need than ever for a united Union rather than a disunited Kingdom. ${ }^{3}$ Yet, again others suggest that the Brexit vote might lead to the crumbling of Jean Monnet's dream of building a Union among people rather than states. Eurosceptic political entrepreneurs like Geert Wilders or Marine Le Pen, for example, hailed the outcome of the British referendum as the beginning of the end of the EU, and claimed that France and the Netherlands would follow suit. ${ }^{4}$ Although the initiation of exit referendums in other

\footnotetext{
2 See, for example, the findings of a survey conducted among economists about the long term costs of Brexit in The Financial Times, 7 January 2017.

${ }^{3}$ See The Financial Times, 29 June 2016.

${ }^{4}$ For a discussion see The Guardian, 12 November 2016.
} 
member states is complicated due to the largely pro-EU parliamentary majorities or constitutional hurdles, the Brexit vote might not bring the people of Europe together, but drive them further apart. Which view will turn out to be the right one, is difficult to determine without a crystal ball, but by looking at some recent survey data this contribution will attempt to shed some light on the consequences of the 23 June referendum result on public opinion in the rest of the EU.

By combining novel survey data with a survey experiment, this contribution examines the possible ramifications of the Brexit vote for public support for EU membership and further integrative steps in Europe. In order to explore the consequences of the British decision to leave the EU, this study relies on data from two surveys that I have designed together with Isabell Hoffmann on behalf of the Bertelsmann Foundation and which were conducted just before and after the Brexit vote in April and August 2016. Moreover, I also present evidence from a survey experiment that was embedded in the August 2016 wave of the survey (De Vries and Hoffmann, 2016a, 2016b). This contribution argues that the Brexit vote will likely be very important for the development of public opinion towards the EU because it sets a precedent for leaving. Based on the benchmark theory of public opinion towards the EU that I have developed more extensively elsewhere (De Vries, 2017), I suggest that support for the EU essentially boils down to a comparison between the benefits of the current status quo of membership and those of an alternative state, namely one's country being outside the EU. The decision of the British to leave the EU provides people with valuable information about the possible economic and political costs and benefits associated with the alternative state.

This contribution reports four findings. First, it documents that support for EU membership was higher immediately after the Brexit vote than before. Although I 
cannot make causal claims about a 'Brexit effect' per se as the data is not based on a panel, these findings seem to suggest that as the uncertainty of leaving manifested itself, the status quo of membership started to look more favourable. Second, this interpretation is strengthened further by the finding that an increase in support for EU membership after Brexit is especially pronounced among those who think that the consequences of Brexit will be bad for the United Kingdom. Third, in order to test my argument in a more causal way, I present evidence from a survey experiment that suggests that when people receive information that reflects badly on their country, and thus makes the alternative state to EU membership look less desirable, support for European integration increases compared to those in the control group. Finally, I suggest that Eurosceptic political entrepreneurs like Marine Le Pen in France or Beppe Grillo in Italy are likely to be crucially important in framing what Brexit might mean for other member states.

These findings are important not only for the way we understand public opinion towards the EU and people's behaviour in EU referendums post-Brexit, but also inform the on-going Brexit negotiations and possible other exit negotiations in the future. The findings presented here suggest that it will be extremely important for EU officials and the national governments of the remaining member states to make sure that the British example is not perceived as setting a positive precedent for leaving. If so, the Brexit vote might spark off claims for exit referendums in other member states. This contribution is structured as follows. In a first step, I conceptualize the role that Brexit might play in the development of public opinion towards the EU in the future based on the benchmark theory and highlight some core expectations. In a second step, I outline the data and experimental design as well as discuss the empirical findings. Third, I highlight the role that Eurosceptic political entrepreneurs might play in framing Brexit. In a final step, I conclude and outline the implications of my findings. 


\section{Public Opinion towards the EU: Understanding the Role of Brexit}

Over the last few decades an extensive literature has developed that examines the determinants of public opinion towards the EU (for an overview see Hobolt and De Vries, 2016). Three key approaches stand out: economic interest, national identity, and party or media elite cues (Hooghe and Marks, 2005). Work on economic interest stresses that market integration favors citizens with higher levels of human capital, such as education and occupational skills, and income. As a result, highly skilled workers and/or high-income earners are expected to be more supportive of European integration (Gabel, 1998). Studies on identity highlight that the European project is not only about market integration, but has also created a sense of European political identity and mutual obligation. By consequence, people's strong and exclusive attachments to their nation as well as negative perceptions of people from other cultures weakens their support for the EU (Hooghe and Marks, 2005, 2009; McLaren, 2002, Kuhn, 2015). A third and final explanation highlights the importance of party and media cues. Most Europeans have few direct experiences with the EU and their detailed knowledge of the EU's inner workings is quite limited as a result. As a result, they rely on party and media 'cues' to overcome their information shortfalls (Ray, 2003; De Vreese and Boomgaarden, 2006; Schuck and de Vreese, 2006; Steenbergen et al., 2007; Hellström, 2008). While government parties have been shown to on average provide positive cues about Europe, opposition parties especially on the extreme left and right end of the political spectrum rally Eurosceptic sentiment (De Vries and Edwards, 2009).

While these approaches have greatly contributed to our understanding of public support and scepticism towards the EU, they provide us with little guidance about how the outcome of the Brexit vote might affect public support for Europe. As I have argued elsewhere (De Vries, 2017), public opinion towards the EU is best understood 
with reference to benchmarks. The benchmark theory suggests that people's attitudes towards Europe are ultimately rooted in a comparison, namely a comparison between the benefits of the current status quo of membership with those associated with an alternative state of one's country being outside the EU. People are only willing to take the risk of voting for their country to leave the EU or casting a ballot for a party that advocates secession when they think that the alternative to membership is better. The alternative state of one's country being outside the EU is largely unknown so people will rely on benchmarks to compensate for these informational shortfalls. These include current national economic performance and quality of government, but also precedents of other countries leaving. While people could in principle also benchmark the alternative state by judging how well countries like Norway or Switzerland fare that have never joined the EU, the transaction costs associated with leaving are fundamentally different. The extent to which people support the status quo of membership thus crucially depends on their beliefs about how well their country would do outside the European bloc and the information they use to form these beliefs.

One can think about this in the following way. Every individual (or group of individuals) derives some benefits from their country through the provision of public goods and services, such as roads, public television, national defence, etc. To be delivered efficiently some public goods and service require international cooperation such as trade. Or certain problems transcend and require international solutions, such as the climate change (Alesina et al., 1996; Hooghe and Marks, 2001). Moreover, being part of the EU institutional architecture may deliver unique goods and services for individuals that the national systems in which they reside by themselves could not. These benefits originating from the advantages of scale, however, can be perceived to come at a cost. Single market access in the EU, for example, currently also implies the acceptance of the free movement of people. This has already proven an important touchstone of dissent within electoral campaigns in 
some member states and was a central issue in the Brexit campaign (Clarke et al., 2017, see also Kriesi et al., 2008). Other perceived costs that have been highlighted by Eurosceptic pundits are that countries have to accept the jurisdiction of the European Court, or engage in some forms of financial guarantees, transfer payments or debt relief efforts, for example, through membership in the Eurozone (De Vries, 2017).

The notion introduced by the benchmark theory, that the viability of the alternative state to membership matters for people's support for the EU, builds on existing work highlighting the importance of national context. In its simplest version, the argument is that national performance affects people's support for integration. SánchezCuenca (2000), for example, argues that those citizens who are dissatisfied with the performance at the national level mainly because of corruption are more willing to transfer sovereignty to the EU level. Moreover, Rohrschneider (2002) shows that citizens who perceive their national democratic institutions to be working well, display lower levels of EU support because they view the EU to be democratically deficient. Furthermore, Rohrschneider and Loveless (2010) highlight that this relationship is conditional upon the overall level of economic prosperity in a country. Citizens in less affluent nations evaluate the EU mainly on the basis of economic performance, while in more affluent nations publics rely mostly on political criteria, such as the functioning of their national democracies. What is different in the benchmark approach is that rather than viewing national context as influencing public opinion in a one-directional way flowing from national to European evaluations, I suggests that the flow can be two-directional or that events in one national context, like the Brexit vote, can impact people's comparisons of the benefits of the status quo of membership as well as the alternative state in another national context (see also, for example, the benchmark approach in economic voting by Kayser and Peress (2012)). 
When we understand support and scepticism as a comparison between the benefits of the current status quo of membership and those associated with an alternative state, the Brexit vote and its immediate aftermath become crucially important. The benefits of the alternative state of one's country being outside the EU are unknown and uncertain. They imply a counterfactual, namely how would my country do were it not a member of the EU? Counterfactuals involve risk. Research suggests that due to imperfect information about what the future may bring, people will most likely favour existing benefits that are known to them over uncertain future ones (see Kahneman and Tversky, 1979 for example). All else being equal, people will thus prefer the status quo. The immediate economic and political effects of the Brexit vote provide people with a crucial piece of information, namely what the costs or benefits of leaving could be. Directly after the vote, some of the possible political and economic costs manifested themselves. The result, for example, sent a shock wave through the stock and currency markets. Over $£ 100$ billion was wiped of the London Stock Exchange, the British pound and the 10-year government bond yield reached record lows, and the UK was stripped of its triple-A rating. In late 2016 and early 2017, many of the stock market losses were recovered.Yet, as the British government negotiations its withdrawl from the EU economic uncertainty will be abound. ${ }^{5}$ Political uncertainty was also considerable thanks initially to Cameron's resignation, but also due to debates about the nature of the exit and the tensions between the constituent parts of the United Kingdom. The new Prime Minister Theresa May took a hard line by stating that Brexit meant Brexit even if that meant leaving the Single Market. ${ }^{6}$ In effect, her mantra 'Brexit means Brexit and we're going to make a success of it' could be seen as a rather successful holding strategy to contain the debate

\footnotetext{
${ }^{5}$ For a discussion see The Economist, 16 July 2016 [as you are referring to uncertainty abounding still now i.e. many months after the referendum I'm not sure this is the best source to use

${ }^{6}$ For a discussion see The Atlantic, 17 January 2017.
} 
about what it all would mean in practice. ${ }^{7}$ The verdict on the exact costs of Brexit will only be known in the long-run, but the process of withdrawal from the EU will be associated with considerable political and economic uncertainty. It is that very uncertainty which feeds into the calculations in the benchmark model.

Based on my benchmark theory of public opinion towards the EU, I would expect support for the EU to increase when the benefits of alternative state look less favourable. When the alternative state of one's country being outside the EU looks less viable, support for the status quo of membership or even further integrative steps in Europe should rise as a result. The economic and political uncertainty immediately after the Brexit vote provides people with more information about the possible counterfactual, namely how well one's country would do outside the EU. Against this backdrop, I expect that immediately following the Brexit vote support for the EU should be higher in the remaining 27 member states. Moreover, it should be higher among those who think that the consequences of Brexit for Britain will be bad on average.

\section{Empirical Results}

I examine the extent to which the economic and political uncertainty following the Brexit vote affects public opinion towards the EU by relying on two waves of surveys that I designed together with Isabell Hoffmann on behalf of the Bertelsmann Foundation (De Vries and Hoffmann, 2016a, 2016b). EUpinions is a bi-annual survey that aims to examine the public mood towards the EU and national political systems in the EU as whole as well as in the six largest member states in terms of population (France, Great Britain", Germany, Italy, Poland and Spain). In 2016 two waves of the

\footnotetext{
${ }^{7}$ I thank Tim Haughton for pointing this out.

${ }^{8}$ Note that in the remaining parts of the contribution, I will refer to Great Britain rather than the United Kingdom. This is because the public opinion data sources that
} 
EUpinons survey were conducted, one before the Brexit vote in April and one after in August. In both waves we asked respondents how they would vote if a membership referendum were held today. Would they vote to 'remain' or to 'leave' the EU? Given that I am interested here in support for remaining in the EU pre- and post-Brexit in the EU-27 figure 1 displays the percentage of those intending to vote remain in the EU excluding Great Britain plus percentages in the five largest member states, namely France, Germany, Italy, Poland and Spain, where we conducted more in-depth studies. Note that I am not able to causally identify a Brexit effect as the surveys are not based on a panel where the same group of people get asked the question twice. Thus there is no way of ruling out that factors other than Brexit might have played a role. That said, the data is unique in the sense that I am able to gauge membership support in hypothetical membership referenda across the EU as a whole and within selected member states.

Figure 1 shows that overall support for one's country to remain in the EU is slightly higher in August compared to April of 2016. The increase is statistically significant for the EU-27 as well as Germany and Poland. The biggest jump in support for remaining in the EU is recorded in Germany with eight per cent. Interestingly, figure 1 shows that support for remaining in the EU is overall quite high, seventy per cent or higher in the EU-27, Germany, Poland and Spain. That said, it is much lower in France and Italy. In fact, in Italy support for remaining inside the EU hovers between the 50 and 55 per cent mark. This is perhaps a reflection of the fact that the EU, and especially the euro, is a very divisive issue in Italian politics thanks in no small part to the critiques voiced by the Five Star Movement against what they call an inefficient European bureaucracy and heartless austerity. Although a referendum on the EU or euro membership is unlikely given the Italian constitutional arrangements,

I use do not always include Northern Ireland. In order to be consistent, I rely on data from Great Britain only. 
if it were called, these findings suggest that the outcome of such a vote would be highly uncertain.

Figure 1: Comparing support for remaining in the EU before and after Brexit
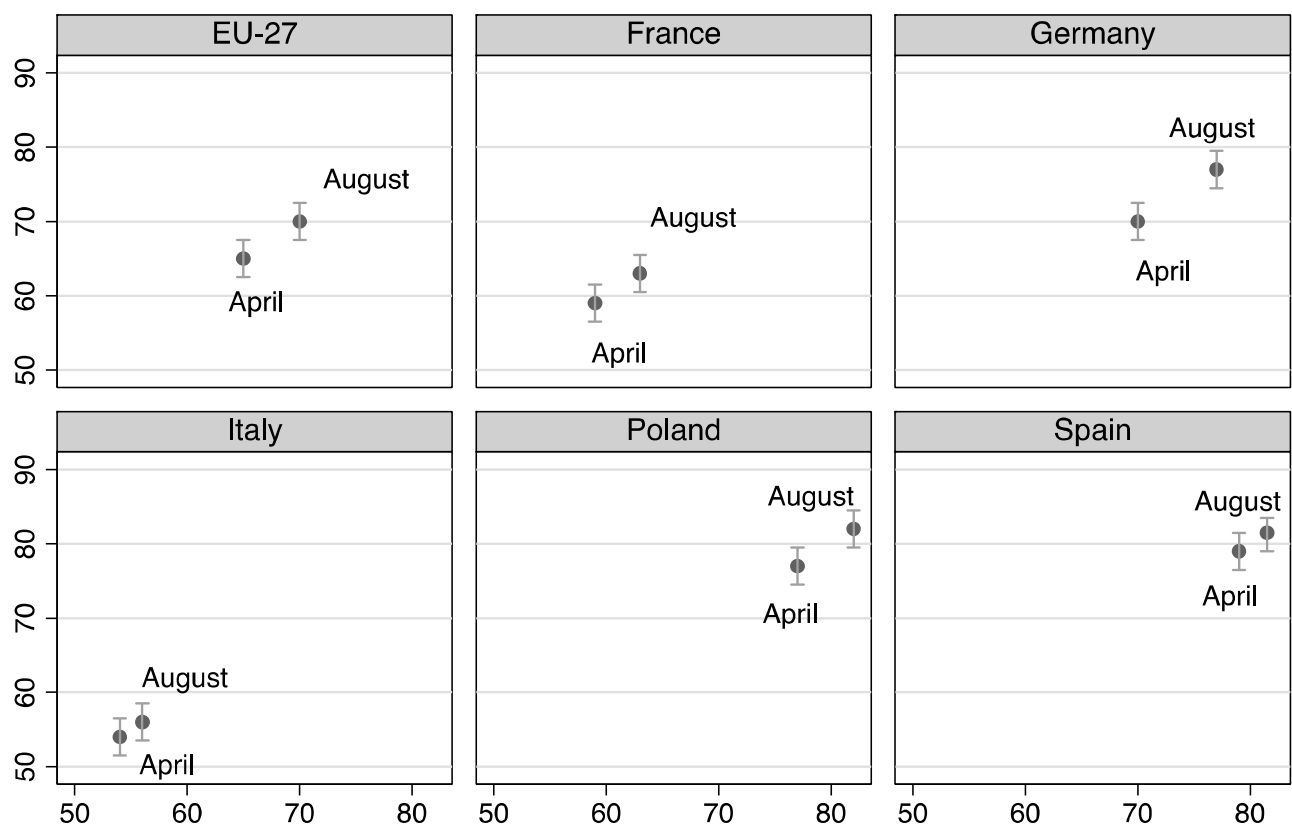

- remain support in \% $\longmapsto 95 \%$ confidence interval

Notes: the dots represent the percentage of people who would vote for their country to remain in the EU if a membership referendum were held today in the April and August waves of the EUpinions survey with 95 per cent confidence intervals.

The findings presented in figure 1 provide some support for the idea that the uncertainty following Brexit might have lowered people's perceptions of how viable it would be for their country to be outside the EU and therefore increased support for membership. Figure 2 provides further support for this interpretation. It plots the support for one's country to remain in the EU for two sets of people, those who think Brexit will have bad consequences for Britain and those who think that the 
consequences will be good. While support for remaining in the EU is close to 70 per cent for those who think that Brexit will have bad consequences for Britain, it is only 38 per cent for those who think the consequences will be good.

Figure 2: Comparing support for remaining in the EU of those who think consequences of Brexit will be good or bad for Britain, EU-27

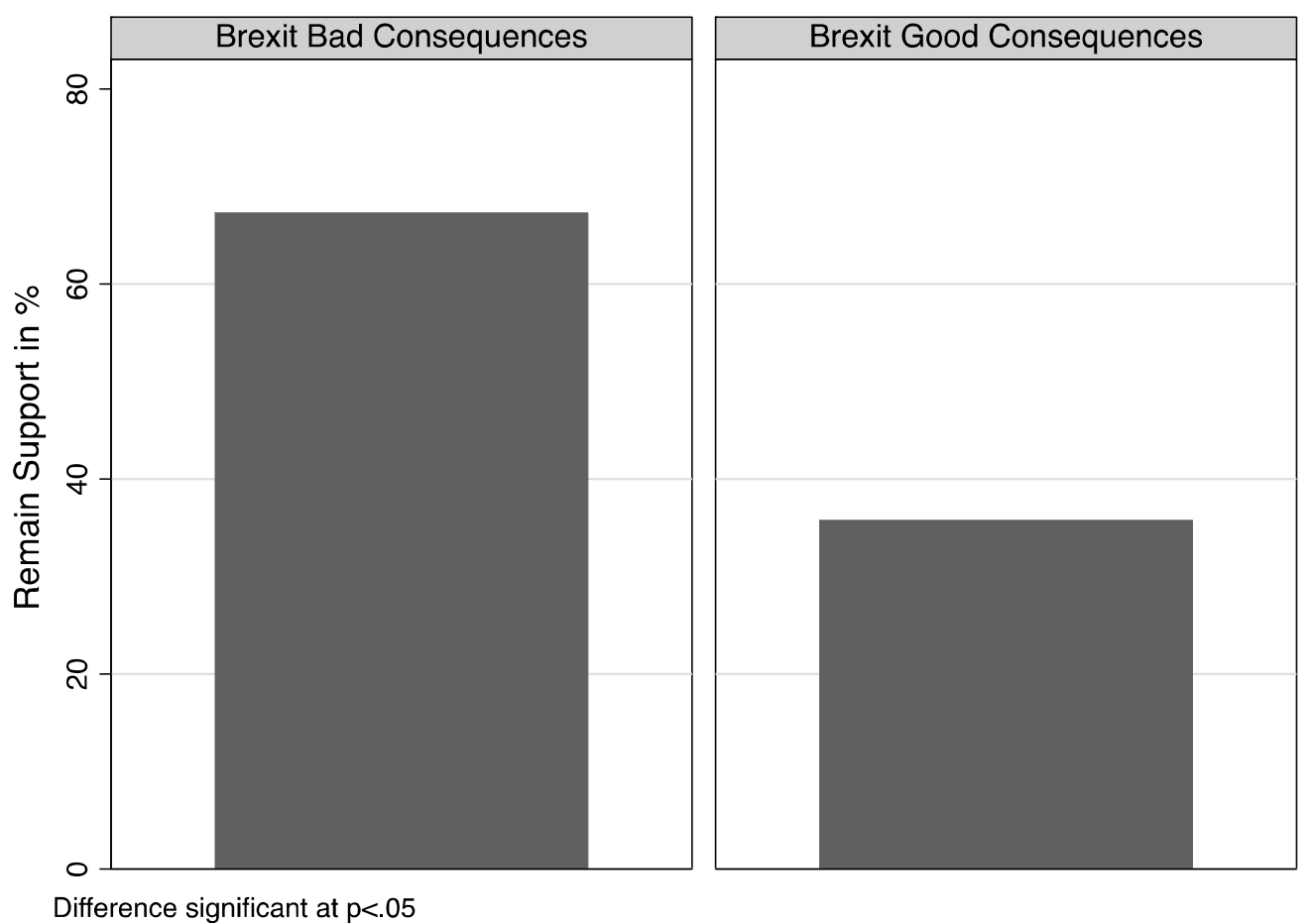

Notes: the bars represent the percentage who would vote for their country to remain in the EU if a membership referendum were held today of those who think that the consequences of Brexit will be bad or good for Britain respectively based on the August wave of the EUpinions survey. The difference in remain support between both groups are statistically significant at a $p<.05$ level (twotailed).

Figure 3 displays the same information but now split by the five largest EU member states. The figure shows the same pattern as in the EU-27 with remain support being highest among those who think that the consequences of Brexit will be bad. The differences are most pronounced in Italy and Spain. They are still considerable and 
statistically significant in France, Germany and Poland, but the differences here are overall somewhat smaller.

Figure 3: Comparing support for remaining in the EU of those who think consequences of Brexit will be good or bad for Britain

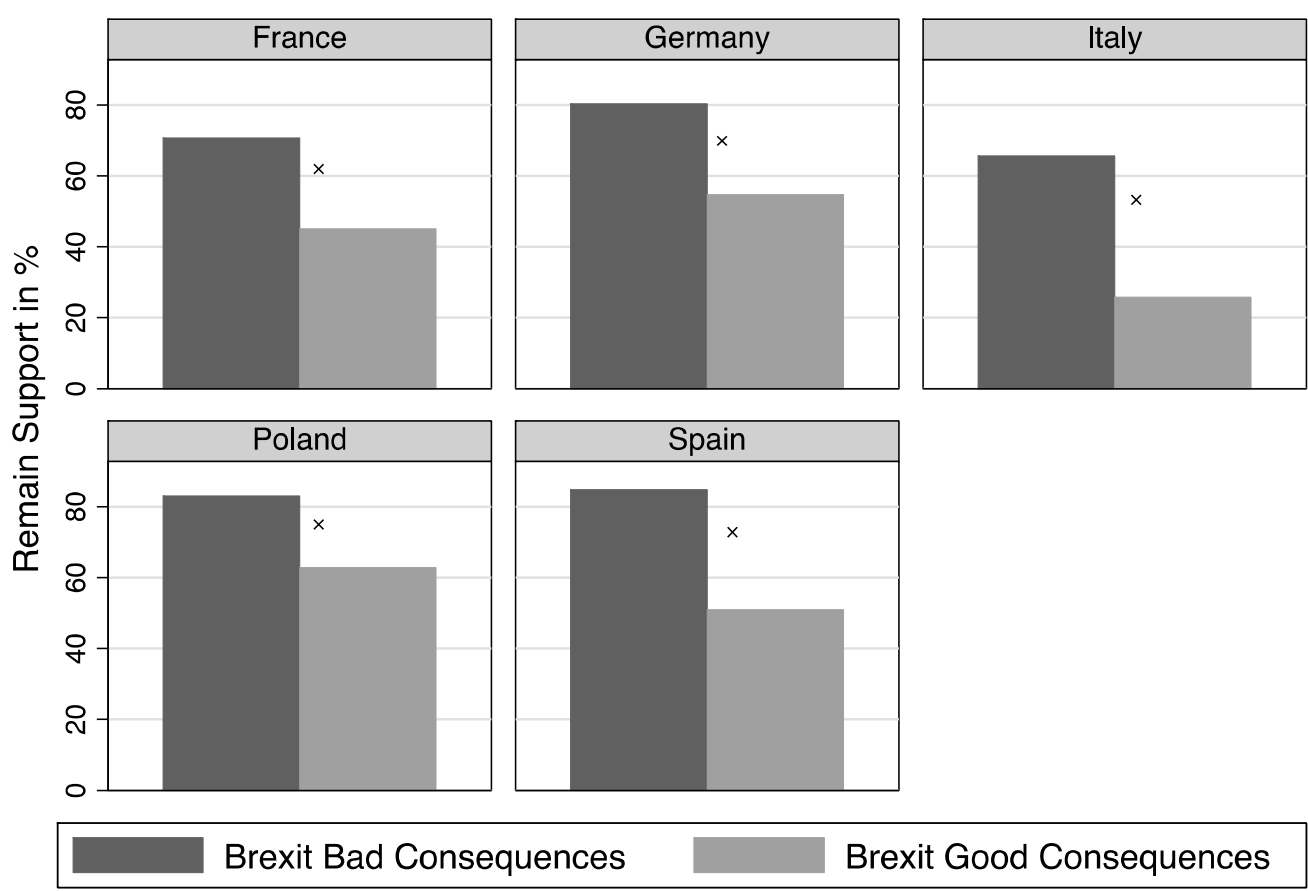

$x$ significant at $p<.05$

Notes: the bars represent the percentage who would vote for their country to remain in the EU if a membership referendum were held today of those who think that the consequences of Brexit will be bad or good for Britain respectively based on the August wave of the EUpinions survey. The crosses indicate that the difference in remain support between both groups are statistically significant at a $\mathrm{p}<.05$ level (two-tailed).

Do these effects persist in a multivariate analysis when I control for a host of other variables like gender, education, age, residency, unemployment and subjective class perception as well as people's views about the politicians and number of foreigners 
in their country. ${ }^{9}$ These controls at least in part tap into the economic interest, national identity and cues explanations outlined earlier. Figure 4 provides this information. It displays the coefficients of a linear probability model where vote intention in a hypothetical EU membership referendum is the dependent variable. All variables are dummy variables coded between 0 minimum value and 1 maximum value to ease comparison. In order for an effect to be statistically significant, the coefficient represented by the grey dot and the 95 per cent confidence intervals represented by the grey line should not fall on or cross the black solid line at the zero point on the $\mathrm{x}$-axis.

Figure 4: Predicting Support for Remaining in the EU

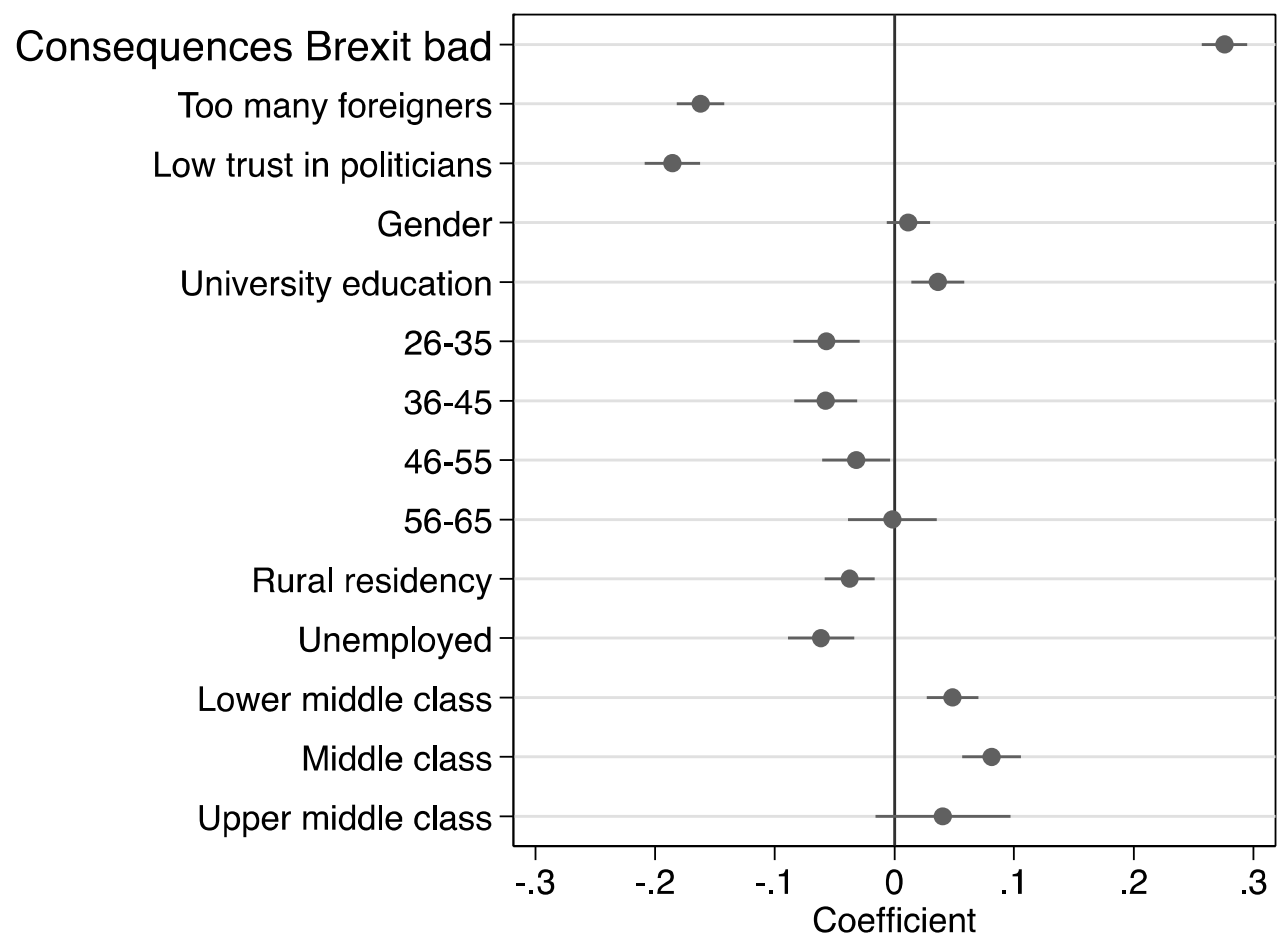

Notes: the dots represent the coefficients of linear probability model where vote intention in a hypothetical EU membership referendum is the dependent variable.. The lines represent the 95 per cent confidence intervals. Country dummies were included in the analysis but are not shown here. The data is based on the August wave of the EUpinions survey.

${ }^{9}$ Specifically, I use the questions 'What is your view on the competence of politicians in your country? ('not at all competent' or 'overall competent') and 'What is your view on the number of foreigners in your country? ('about right' or ' too many'). 
Figure 4 suggests that if people think that the consequences of Brexit will be bad for Britain the likelihood of voting for remaining inside the EU increases substantially. This effect remains statistically and substantially significant even if we control for a host of other factors such as skills levels, age or people's views about the politicians or number of foreigners in their country. In fact, the effect of people's expectations about the consequences of Brexit is larger than any other factor included in the model. When it comes to the controls, we find that as people become more suspicious of the number of foreigners or the politicians in their country the likelihood of voting to remain in the EU decreases, while having a university education, being female or middle class increases it. Finally, being older, unemployed or living in a more rural area decreases the support for one's country to remain in the EU. Interestingly, the factors that decrease or increase people's likelihood to vote for their country to remain in the EU within the 27 member states are similar than those reported for voting behaviour in the Brexit referendum (Hobolt, 2016).

Although the results presented thus far seem to suggest that the Brexit vote and the political and economic uncertainty surrounding the decision of the British people to leave the EU might have sparked off more support for the EU in the remaining 27 member states, they also raise questions about causality. The descriptive statistics presented in figures 1 through 3 are interesting but do not allow us to rule out possible other factors that changed between April and August 2016. Moreover, the multivariate analysis presented in figure 4 showing the effect of people's views about the possible consequences of Brexit for their likelihood to vote to remain in or leave the EU in membership referendum might suffer from endogeneity. Do people view the consequences of Brexit to be bad because they support the EU or the reverse? In order to deal with these concerns and tackle the issue of causality more 
directly, I also embedded an experiment in the August wave of EUpinions in 2016. The experiment was run in nine countries: Austria, France, Great Britain, Germany, Hungary, Italy, the Netherlands, Poland and Spain.

The survey experiment seeks to capture the effect of negative information about the viability of an alternative to EU membership on support for European integration. The experiment consisted of one treatment and one control group. Respondents were randomly assigned to either the control or treatment group. The control group received no information, while the treatment group received a vignette stating that 'According to international organizations, corruption in [COUNTRY] seems to be on the rise in recent years.' Both the control and treatment were then asked about their national and European regime evaluations. I expect people's EU evaluations to increase when they are exposed to information about an increase in corruption at the national level. Respondents were also asked about the importance of corruption for their voting decision. The importance of corruption question was introduced as a check to establish if the experimental treatment indeed raised the importance of corruption in people's minds. It constitutes a so-called manipulation check. The importance of corruption was captured by the following survey item: 'How important is corruption to you as a factor in deciding who to vote for?' Answers range from 0) 'not important at all' to 10) 'very important'. In order to make sure that respondents responded to the corruption vignette in the way I would expect and attach importance to it, I examined if corruption is more important in deciding which party to vote for among people assigned to the treatment group. It was. The treatment raised the importance of corruption in people's minds by .67, two-thirds of a point on an 11-point scale, and this effect was statistically significant.

After having established that the experimental vignette worked, I examine the effect of being exposed to the corruption vignette on people's support for more or less political and economic integration in Europe. People could answer that they wished 
to see (1) less political and economic integration, (2) the same political and economic integration, or (3) more political and economic integration. In table $1 \mathrm{I}$ show the effect of the corruption vignette on support for European integration using both a linear probability model as well as an ordered logit model. The latter model is more sensitive to the ranking between the three categories. Table 1 shows that no matter the model estimated, being exposed to the corruption vignette increases people's support for European integration. This result supports the benchmark theory of public opinion towards the EU and suggests that providing people with negative information about their country increases people's evaluations of the benefits of European integration. When the alternative state looks less viable, because of negative information about one's national political system operates, support for the EU increases as a result.

Table 1: The effect of corruption vignette on support for European integration

\begin{tabular}{|c|c|c|}
\hline & \multicolumn{2}{|c|}{ DV: Support for European Integration } \\
\hline & OLS & Ordered Logit \\
\hline Corruption Vignette & $\begin{array}{l}.04^{*} \\
(.02)\end{array}$ & $\begin{array}{l}.09^{*} \\
(.05)\end{array}$ \\
\hline $\begin{array}{l}\text { Constant } \\
\text { Cut1/Cut2 }\end{array}$ & $\begin{array}{l}1.89^{*} \\
(.04)\end{array}$ & $\begin{array}{c}-.18 / .66 \\
(.10) /(.10)\end{array}$ \\
\hline $\begin{array}{l}\text { Individual Level } \\
\text { Covariates }\end{array}$ & $\rightarrow$ & $\rightarrow$ \\
\hline $\begin{array}{l}\text { Country } \\
\text { Dummies } \\
\end{array}$ & $\rightarrow$ & $\rightarrow$ \\
\hline $\mathrm{R}^{2 /}$ Wald $\mathrm{Chi}^{2}$ & .09 & $508^{*}$ \\
\hline $\mathrm{N}$ & 11,185 & 11,185 \\
\hline
\end{tabular}

Note: table entries are OLS or ordered logit regression coefficients with standard errors in parentheses. * significant at $\mathrm{p} \leq .05$ (one-tailed). 


\section{Role of Eurosceptic Political Entrepreneurs}

Taken together, the findings presented so far suggest that the outcome of the Brexit vote and the political and economic uncertainty following provided a powerful signal for people in the remaining 27 member states about the potential costs and benefits of exit. The decision of the British to leave the EU provides people with more information about the risks associated with leaving. The data presented here are from August 2016 and suggest that Brexit largely set a negative precedent for leaving. Yet, for how long will this be the case? At the time of writing, many institutions, like the Bank of England or the International Monetary Fund, have upgraded their economic outlook on Britain and the economic future might look much better than anticipated. ${ }^{10}$ If these developments persist, the British precedent could also spark off demands for exit. Eurosceptic political entrepreneurs are likely to play a crucial role in this respect. When it comes to Eurosceptic political parties existing work suggests that they mainly come in two varieties: hard and soft (Szczerbiak and Taggart 2008; Treib, 2014). Szczerbiak and Taggart (2008) use the term soft euroscepticism to signify political parties that oppose certain policies or institutional aspects at the European level, but do not oppose the entire project as such. Hard euroscepticism is a label for parties that strongly oppose the EU. These parties reject the idea of European integration and campaign for their countries to leave. Examples of soft Eurosceptic parties are Podemos in Spain or the Linke in Germany for example, while Front National in France or the Partij van de Vrijheid in the Netherlands fall in the hard Eurosceptic category. Party leaders of hard Eurosceptic parties like Marine Le Pen or Geert Wilders celebrated the Brexit as a victory and called for exit referendums in their own countries. Marine Le Pen tweeted immediately after the vote that Brexit was a '[v]ictory for freedom! As I have been asking for years, we must now have the same referendum in France and EU

${ }^{10}$ See The Guardian, 11 January 2017 and 4 October 2017. 
countries' ${ }^{11}$ Geert Wilders added: 'Hurrah for the British! Now it is our turn. Time for a Dutch referendum' ${ }^{12}$

Figure 5 below shows people's expectations about the consequences of Brexit for Britain split by party supporters in the five largest EU member states in terms of population for which we carried out more in-depth surveys. People were asked what they think the consequences for Brexit for Britain and could choose between three answer categories: 1) I think the consequences will be good, 2) I think the consequences will be bad, or 3) I am unsure what the consequences will be. The figure shows that party supporters of hard Eurosceptic parties on the right, the Alternative für Deutschland (AfD), Front National (FN), Lega Nord (LN), Prawo I Spawiedliwość (PiS), as well as on the left Front de Gauche (Gauche) and Movimente Cinque Stelle (MVCS) (although the latter party is difficult to place on a left-right scale) are much more likely to be either unsure about or much less likely to think that the consequences of Brexit will be bad for Britain compared to supporters of the other parties in the system. Hence, already in August 2016 when the economic and political uncertainty made the outlook of Brexit look pretty negative, supporters of hard Eurosceptic parties were already less pessimistic or generally unsure about what the consequences of Brexit would be for Britain. Given that since then the economic forecasts for Britain by the Bank of England or International Monetary Fund turned out to be better than expected, hard Eurosceptic political entrepreneurs might try to use the example of Brexit to rally support for a euro or EU membership referendum in their own countries. Although constitutional rules and pro-EU mainstream party majorities make referendums less likely, if they were to take place

\footnotetext{
${ }^{11}$ See https://twitter.com/mlp officiel/status/746209726673760262 (accessed 16 November 2016).

${ }^{12}$ See https://twitter.com/geertwilderspvv/status/746199016128421889 (accessed 16 November 2016).
} 
a sizable segment of the population might be swayed by arguments that their country would be better outside the EU (or Eurozone).

Figure 5: Comparing support for remaining in the EU of those who think consequences of Brexit will be good or bad for Britain, by party identifiers in five countries 

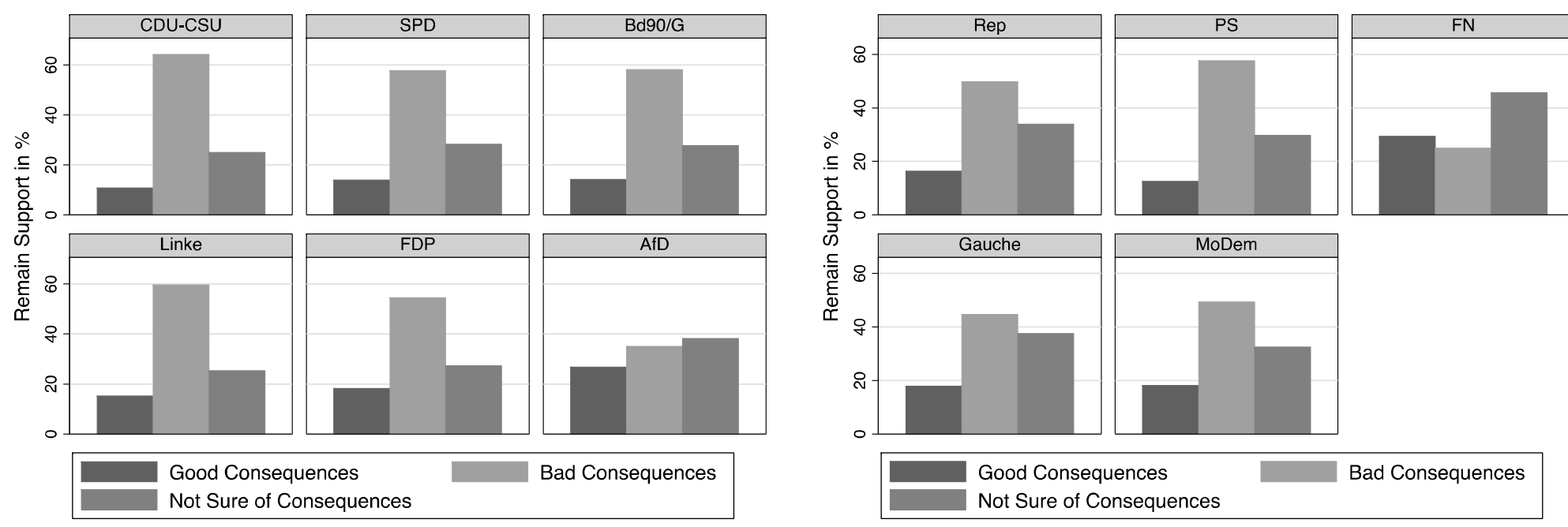

Differences significant at $p<.05$

Differences significant at $p<.05$
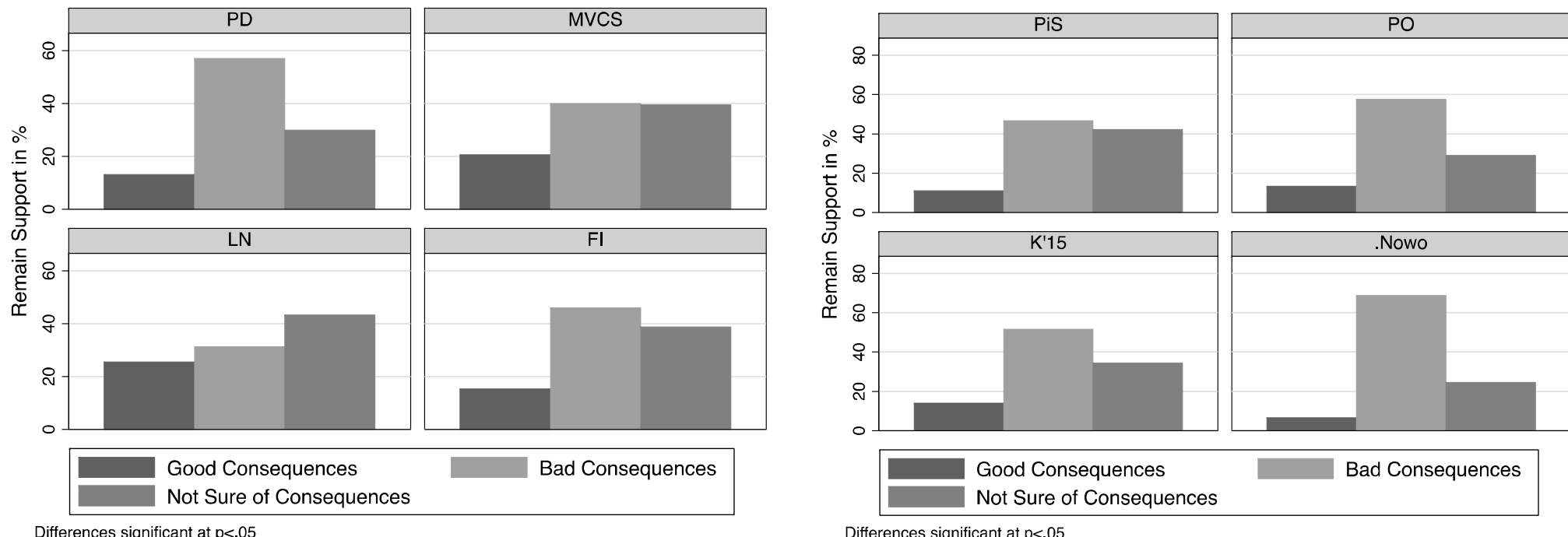

Differences significant at $p<05$ 


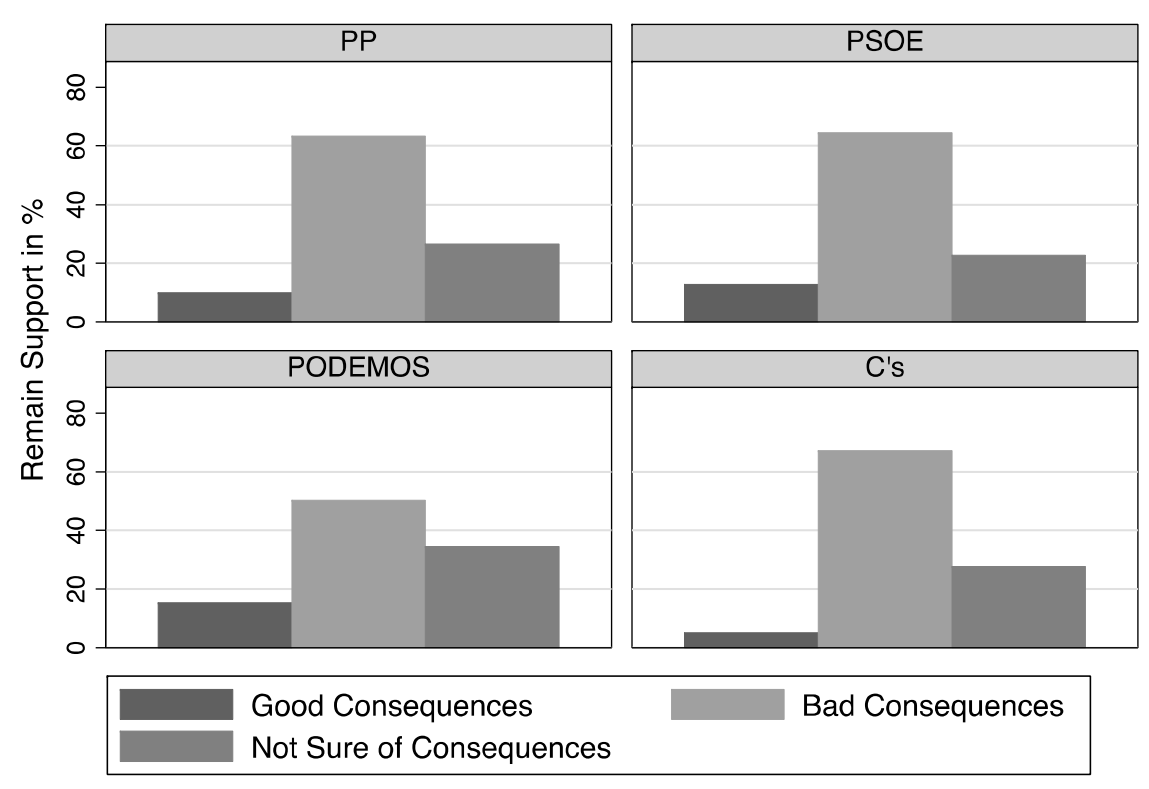

Differences significant at $\mathrm{p}<.05$

Notes: the bars represent the percentage who would vote for their country to remain in the EU if a membership referendum were held today of those who think that the consequences of Brexit will be bad or good for Britain respectively based on the August wave of the EUpinions survey split by party supporters. The party acronyms stand for: CDU-CSU-Christlich Demokratische Union-Christlich-Soziale Union, SPD-Sozialdemokratische Partei

Deutschlands, Bd90/G-Bündnis 90/Die Grünen, Linke-Die Linke, FDP-Freie Demokratische Partei, AfD-Alternative für Deutschland;Rep- Les Républicains, PS -Parti Socialiste, FN -Front National, Gauche-Parti de Gauche, MoDem-Mouvement démocrate; PD-Partido Democratico, MVCS- Movimento 5 Stelle, LNLega Nord, FI-Forza Italia; PiS-Prawo I Spawiedliwość, PO-Platforma Obywatelska, K'15-Kukiz'15, .Nowo-.Modern; PP - Partido Popular, PSOE - Partido Socialista Obrero Español, C's -Cuidadanos. 


\section{Conclusion and Discussion}

Although prior to the Brexit referendum experts had already pointed out that the outcomes of EU referendums are notoriously hard to predict, the outcome of the vote was nonetheless a shock for many. The polls leading up to the referendum predicted a small lead for the Remain side campaigning for Britain to stay in the EU. As the results of the referendum started pouring in from around the country, a different picture started to emerge. The polls got it wrong. 51.9 per cent of the British people voted for their country to leave. The outcome of the vote is of historical importance. One of the six largest members of the EU in terms of population turned their back on Europe. The vote demonstrated that exit is a possibility. This contribution suggests that by setting a precedent for exit, the Brexit vote is likely to cast a long shadow on public opinion towards the EU in the remaining 27 member states. Based on my benchmark theory, I have conceived public opinion towards the EU as the result of a comparison, namely a comparison between the benefits of the status quo of membership and the alternative state, one's country being outside. The alternative state of one's country being outside the EU is largely unknown so people will rely on benchmarks to compensate for these informational shortfalls. The precedent of another country leaving is likely to be an important benchmark. (De Vries 2017). It provides people with a valuable source of information that allows them to inform their beliefs about how well their country would do outside the EU.

This study documents four findings. First, it demonstrated that support for EU membership was higher immediately after the outcome of the Brexit vote compared to before it. Although I do not have panel data and therefore cannot rule out that other factors than Brexit were important in this change, these findings do support the idea that the political and economic uncertainty immediately following the vote, made the status quo of membership looks more favourable and the prospect of leaving less so. Second, the findings suggested that an increase in support for EU 
membership after Brexit is especially pronounced among those who think that the consequences of Brexit will be bad for the United Kingdom. This fits the interpretation that when the Brexit is perceived as setting a bad precedent because of the negative political and economic consequences, support for remaining in the EU should increase in the other member states. Thinking that the consequences of Brexit will be bad is related to prior levels of support for integration, so in order to test my argument in a more causal way, I present evidence from a survey experiment. The experimental evidence showed that when people receive information that reflects badly on their country, and thus makes the alternative state look less favorable, support for European integration is higher compared to those in the control condition. This finding suggests that how people view Brexit and what the Brexit experience tells them about the prospects of their own country outside the EU will be of crucial importance for shaping people's support for the EU in the future. Arguably, Eurosceptic political entrepreneurs that vocalize demands for exit will be crucially important in framing what Brexit means in popular debate. Indeed, I find that supporters of hard Eurosceptic parties are much less likely to view the consequences of Brexit as bad for Britain or are much more unsure about what the consequences will be compared to supporters of more pro-EU parties.

Why do these findings matter? First, they inform current debates about public opinion towards the EU. Public opinion towards the EU has largely been understood as a reflection of developments at the EU level. People stand to gain and lose from integration economically or in terms of their sense of belonging and will therefore support or be sceptical about the European project. This contribution suggests although these factors are undoubtedly important, the degree to which people perceive that their country would survive or even thrive outside the EU is key, even when they themselves might stand to gain for market and political integration in Europe. If people think that the benefits of the alternative state exceed those of EU 
membership, support for integration may be low regardless of the overall positive benefits of integration for themselves or their country.

Second, the findings presented here inform the scholarly debate about which issues determine people's choices in EU referendums. This debate has pitted the view that people use EU referendums as means to signal their evaluations of national government or elites more generally (Franklin et al., 1994), against the idea that people's attitudes towards European integration matter (Garry et al., 2005; Suine and Svensson, 1993). This study suggests that understanding decision making in EU referendums as either EU related (EU issue voting) or not (second order voting) might not be that helpful. Understanding people's support for the EU as a comparison between the status quo of membership and alternative state suggests that by definition evaluations about both how the EU and one's own country, and even other countries are doing, will matter.

Finally, the results presented here also inform developments in EU politics now and in the future. They suggest that it will be crucially important for the EU and the national governments of the remaining 27 member states to make sure that the British example does not set a positive precedent. When the economic and political fallout turns out to be comparatively mild, and the British government is able to negotiate a relatively good deal while at the same time limiting immigration, this might have grave consequences for the support for leaving the EU in other countries. In countries with vocal Eurosceptic political entrepreneurs, like France or Italy for example, having a positive example of how exit can combine trade with immigration controls might turn out to be a gamble that people might be willing to take. In these countries leaving the EU will mean leaving the Euro as well which makes the transaction costs so much higher, yet how high is the question? Moreover, in most of 
the remaining EU member states mainstream parliamentary majorities that are proEU or constitutional hurdles make exit referendums rather unlikely, but that said if a referendum were to take place, the findings presented here would suggest that the outcome would be highly uncertain. 


\section{References}

Alesina, A., Perotti, R and Spolaore, E. (2015) 'Together or separately? Issues on the costs and benefits of political and fiscal unions'. European Economic Review, Vol. 39 No. 3, pp. 751-758.

Clarke, H., Goodwin, M. \& Whiteley, P. (2017) Brexit! Why Britain Voted to Leave the European Union. (Cambridge: Cambridge University Press).

De Vreese, C.H. and Boomgaarden, H. G. (2006) 'Media effects on public opinion about the enlargement of the European Union.' JCMS, Vol. 44 No. 2, pp. 419-436.

De Vries, C. E. (2017) Euroscepticism and the Future of European integration. Forthcoming with Oxford University Press).

De Vries, C. E., and Edwards, E. E. (2009) 'Taking Europe to its extremes extremist parties and public Euroscepticism' Party Politics, Vol. 15 No. 1, pp. 5-28.

De Vries, C. E. and Hoffmann, I. (2016a) 'A European Finance Minister with Budget Autonomy? Need for reforms of the Eurozone and their potential, given public opinion in Europe'. Report for the Bertelsmann Foundation. Available on-line at $<<$ https://www.bertelsmann-

stiftung.de/fileadmin/files/user upload/EZ eupinions Finance Minister 2016 ENG. $\underline{p d f}>>$

De Vries, C. E. and Hoffmann, I. (2016b) 'Fears Not Values: Public opinion and the populist vote in Europe'. Report for the Bertelsmann Foundation. Available on-line at: $<<$ https://www.bertelsmannstiftung.de/fileadmin/files/user upload/EZ eupinions Fear Study 2016 ENG.pdf $\gg>$ 
Franklin, M., Marsh, M., and McLaren, L. (1994) 'Uncorking the bottle: Popular opposition to European unification in the wake of Maastricht' JCMS,, Vol. 32 No. 4, pp. $455-472$.

Gabel, M. J. (1998) Interests and integration: Market liberalization, public opinion, and European Union. (Ann Arbor: University of Michigan Press).

Garry, J., Marsh, M., \& Sinnott, R. (2005). “Second-order'versus 'Issue-voting' Effects in EU Referendums Evidence from the Irish Nice Treaty Referendums'. European Union Politics, Vol. 6 No. 2, pp. 201-221.

Goodwin, M. J., and Heath, O. (2016) 'The 2016 Referendum, Brexit and the Left Behind: An Aggregate-level Analysis of the Result' ,Political Quarterly, Vol. 87 No. 3, pp. 323-332.

Hellström, J. (2008) ‘Who Leads, Who Follows? Re-Examining the Party-Electorate Linkages on European Integration', Journal of European Public Policy, Vol. 15 No. 8, pp. $1127-44$.

Hobolt, S. B. (2009) Europe in question: Referendums on European integration (Oxford: Oxford University Press).

Hobolt, S. B. (2016) 'The Brexit vote: a divided nation, a divided continent', Journal of European Public Policy, Vol. 23 No. 9, pp. 1259-1277.

Hobolt, S. B., and De Vries, C. E. (2016) 'Public support for European integration' Annual Review of Political Science, Vol. 19, pp. 413-432. 
Hooghe, L., and Marks, G. (2001) Multi-level governance and European integration. (PLACE?: Rowman \& Littlefield).

Hooghe, L. and Marks, G. (2005) 'Calculation, community and cues public opinion on European integration', European Union Politics, Vol. 6 no. 4, pp. 419-443.

Hooghe, L., and Marks, G. (2009) 'A postfunctionalist theory of European integration: From permissive consensus to constraining dissensus', British Journal of Political Science, Vol. 39 No. 1, pp. 1-23.

Kahneman, D., and Tversky, A. (1979). 'Prospect theory: An analysis of decision under risk'. Econometrica, Vol. 47, No. 2, pp. 263-291.

Kayser, M. A. and Peress, M. (2012) 'Benchmarking Across Borders: Electoral Accountablity and the Necessity of Comparison', American Political Science Review, Vol. 106 No. 3, pp. 661-684.

Kriesi, H., Grande, E., Lachat, R., Dolezal, M., Bornschier, S., and Frey, T. (2008) West European politics in the age of globalization (Cambridge: Cambridge University Press).

Kuhn, T. (2015) Experiencing European integration: Transnational lives and European identity (Oxford: Oxford University Press).

McLaren, L. M. (2002) 'Public support for the European Union: cost/benefit analysis or perceived cultural threat?' Journal of Politics, Vol. 64 No. 2, pp. 551-566.

Ray, L. (2003) 'When parties matter: The conditional influence of party positions on voter opinions about European integration', Journal of Politics, Vol. 65 No. 4, pp. 978994. 
Rohrschneider, R. (2002) 'The democracy deficit and mass support for an EU-wide government', American Journal of Political Science, Vol. 46 No. 2, pp. 463-475.

Rohrschneider, R., and Loveless, M. (2010) 'Macro salience: How economic and political contexts mediate popular evaluations of the democracy deficit in the European Union', Journal of Politics, Vol. 72 No. 4, pp. 1029-1045.

Sánchez-Cuenca, I. (2000) 'The political basis of support for European integration', European Union Politics, Vol. 1 No. 2, pp. 147-171.

Schuck, A., and De Vreese, C. H. (2006) `Between risk and opportunity: News framing and its effects on public support for EU enlargement', European Journal of Communication, Vol. 21 No. 1, pp. 5-32.

Steenbergen, M. R., Edwards, E. E., and De Vries, C. E. (2007) ‘Who's cueing whom? Mass-elite linkages and the future of European integration', European Union Politics, Vol. 8 No. 1, pp. 13-35.

Szczerbiak, A., \& Taggart, P. (eds.) (2008). Opposing Europe? The comparative party politics of Euroscepticism. Volume 1: Case studies and country surveys. Oxford University Press,

Treib, O. (2014) 'The voter says no, but nobody listens: causes and consequences of the Eurosceptic vote in the 2014 European elections', Journal of European Public Policy, Vol. 21 No. 10, pp. 1541-1554. 
Van De Wardt, M., De Vries, C. E., and Hobolt, S. B. (2014) 'Exploiting the cracks: Wedge issues in multiparty competition', Journal of Politics, Vol. 76 No. 4, pp. 986999. 